Article

\title{
Experimental Data and Simulations of Performance and Thermal Comfort in a Patient Room Equipped with Radiant Ceiling Panels
}

\author{
Paolo Valdiserri $^{1, *(\mathbb{D}}$, Silvia Cesari ${ }^{2}$ (D) Maddalena Coccagna $^{3}{ }^{(1)}$, Pasquale Romio ${ }^{4}$ \\ and Sante Mazzacane ${ }^{3}$ \\ 1 Department of Industrial Engineering, Alma Mater Studiorum-University of Bologna, 40136 Bologna, Italy \\ 2 Department of Architecture, University of Ferrara, 44121 Ferrara, Italy; silvia.cesari@unife.it \\ 3 CIAS Research Center for Pollution Control in High Sterility Rooms, Department of Architecture, \\ University of Ferrara, 44122 Ferrara, Italy; maddalena.coccagna@unife.it (M.C.); \\ sante.mazzacane@unife.it (S.M.) \\ 4 AUSL Bologna, Via Altura 7, 40139 Bologna, Italy; pasquale.romio@ausl.bologna.it \\ * Correspondence: paolo.valdiserri@unibo.it; Tel.: +39-051-2093303
}

Received: 24 October 2020; Accepted: 8 December 2020; Published: 11 December 2020

check for updates

\begin{abstract}
Hospitals require the highest energy demands in non-residential buildings. They provide healthcare 24/7/365 and, at the same time, they ensure indoor air quality, thermal comfort and sterility. However, several studies reveal that high indoor temperatures and low relative humidity (RH) are often perceived in patient rooms during the heating season, suggesting an important energy saving potential. Against this background, radiant ceiling panel (RCP) systems result to be one of the most appropriate solutions as they allow to achieve significant energy savings while providing the highest level of thermal and acoustic comfort, as well as of infection control. In the present study the microclimatic survey of a patient room at Maggiore Hospital in Bologna, Italy, equipped with an air conditioning system integrated with RCP, has reported occupant thermal discomfort. Experimental data were used to calibrate a building model and dynamic building energy simulations were carried out to analyse indoor air temperature, relative humidity, predicted mean vote (PMV) and predicted percentage of dissatisfied (PPD) indexes under different inlet air temperatures, to identify the best design conditions for energy efficiency and thermal comfort improvement. It was found that the highest advantages can be obtained when neutral air is supplied.
\end{abstract}

Keywords: radiant ceiling panel; hospital patient room; microclimatic monitoring; thermal comfort; PMV; PPD; model calibration; dynamic building energy simulations; TRNSYS

\section{Introduction}

Hospitals require the highest energy demands in non-residential buildings, as they provide healthcare $24 \mathrm{~h}$ a day and 7 days a week while performing energy-consuming activities and hosting thousands of employees, patients, and visitors. The approximately 15,000 hospitals across the European Union account for almost $10 \%$ of the total EU energy use [1] and produce about $5 \%$ of the EU carbon dioxide emissions [2]. In England, the carbon footprint of the Nation Health Service represents $40 \%$ of all greenhouse gas (GHG) emissions from the public sector [3], while in Italy healthcare is responsible for $5 \%$ of the national $\mathrm{CO} 2$ footprint [4].

High levels of energy are required by multiple end-use categories, including heating, cooling, humidification, service water heating and electricity consumption, as well as to ensure indoor air quality, thermal comfort and sterility according to the tightening mandatory requirements [5-8]. 
Heating, Ventilation and Air Conditioning (HVAC) systems result to be responsible for the highest energy consumption rates in hospitals, reaching values ranging from $51 \%$ to $65 \%$, together with the highest volumes of GHG emissions (about 47\%) [9-11]. However, a growing number of studies have uncovered that thermal discomfort related to high indoor temperatures and low relative humidity (RH) levels is often perceived in patient rooms during winter due to the poor regulation of building plants, thus revealing an important energy saving potential.

In a study by Verheyen et al., field measurements of thermal comfort were performed for 99 patients in different wards (maternity, medicine oncology, neurology and gastroenterology, abdominal surgery and thoracic-vascular surgery); the analysis resulted in operative temperatures that were too high and low relative humidity levels during the heating season, with particularly critical values for oncology patient rooms [12]. Patient dissatisfaction due to high indoor air temperatures and low relative humidity was also described by other studies. [13,14].

Two studies carried out by Hashiguchi et al. in 2008 [15] and 2005 [16], focused on patient and staff thermal comfort, performed in situ measurements in patient rooms, nurse stations and corridors in winter. The levels of relative humidity were in the range of $29-37 \%$ and the humidity ratio stayed around $5 \mathrm{~g} / \mathrm{kg}$ over a $24 \mathrm{~h}$ period, values known to promote the spread of influenza viruses. It was found that $54.9 \%$ and $73.4 \%$ of patients suffered from itchy skin and thirst, respectively, which resulted to be the same conditions in which the majority of the staff members were working. Low air humidity levels perceived both by patients and staff in winter were outlined also in Refs. [17-19], reaching a mean value of $16.2 \%$ for the staff and $22.0 \%$ for the patients as reported by Skoog et al. [20].

Even though many authors investigated energy consumption and thermal environment of operating rooms [21-27], laboratories [28], hospital wards [29-32], intensive care units, examination and treatment rooms [33], few studies focused on maternity unit and its patient rooms, although these are characterised by high energy consumption and patient vulnerability from both a physical and psychological perspective. To our knowledge, very few studies analysed maternity unit from an energy perspective $[34,35]$ as well as from thermal comfort point of view [12,35,36].

Taking into consideration that, in a 5\% operating environment, a USD 1 savings in annual energy costs is equivalent to an increase of USD 20 in annual revenue [37], and that hospital energy saving potential has been extensively examined [38] and found to range between $35-40 \%$ up to $71-77 \%[39,40]$, it is important to further analyse patient rooms both in terms of energy efficiency and thermal comfort. Indeed, despite the significant reduction in hospital beds due to both the ongoing shift from inpatient toward outpatient care and the tighter budget constraints, patient rooms still represent a significant percentage of the conditioned floor area in existing hospitals [41].

\subsection{Hydronic Heating Systems}

Central heating systems can be separated into hydronic systems, using water as heat transfer medium, and forced-air ones, also known as dry systems. Healthcare facilities and especially hospital wards are usually conditioned by means of hydronic systems-having water a higher heat transfer efficiency than air-integrated with natural, mechanical or hybrid ventilation to ensure indoor air quality (IAQ), infection control and thermal comfort during the cooling season [42]. Furthermore, taking into account the strong necessity of preventing intra-hospital infection and transmission of the novel COVID-19 pandemic, the use of mixed conditioning systems in hospitals is being preferred, with hydronic systems to meet heating and cooling energy demand and primary air systems to control IAQ and sterility.

Based on the supply water temperature and the related type of heat emitter, hydronic heating systems are divided into four groups. High temperature systems operate with a temperature of supply water up to $95^{\circ} \mathrm{C}$, return up to $70^{\circ} \mathrm{C}$ and use conventional hydronic radiators. In medium-temperature systems, low-temperature radiators with a supply water temperature of about $55{ }^{\circ} \mathrm{C}$ and return between 35 and $40^{\circ} \mathrm{C}$ are employed to transmit energy to the space. Low-temperature systems use supply water at around $45^{\circ} \mathrm{C}$ and return at $25-35^{\circ} \mathrm{C}$ in fan coil units. Finally, radiant wall, floor or 
ceiling panels are employed in very low-temperature systems, where supply water temperature can be reduced to $35^{\circ} \mathrm{C}$ or lower and return is almost $25^{\circ} \mathrm{C}$ [43-45].

Radiators transfer thermal energy to the space by using both radiation and convection. Despite being the most prevalent type of heating unit in hydronic systems [46], they are responsible for significant energy consumption. Indeed, besides the high temperature of supply water involved, radiators usually operate on constant flow with on/off control strategy. Furthermore, in the case of a not well-insulated building envelope, energy use is even higher due to the higher heat losses, which dramatically increase with a supply/return water temperature of around $70 / 55^{\circ} \mathrm{C}$, respectively $[47,48]$. On the contrary, low temperature heat emitters consume decisively less primary energy-up to half-compared to traditional high-temperature ones [49-52]. Furthermore, several studies investigating low-temperature heating units and conventional radiators in residential and non-residential buildings uncovered that occupants experienced a better indoor thermal comfort in spaces heated by low-temperature systems $[43,44,53]$.

Among low-temperature heat emitters, fan coil units heat the space by forced convection through the fan. In comparison to conventional hydronic systems, it is thereby possible to achieve a high heat transfer, even at low flow temperatures. Compared to radiant floors, fan coils operate with higher water temperatures and have shorter response times thanks to the lower thermal inertia, thus allowing the set-point temperature to be reached more quickly.

However, thermal discomfort due to perceived air flow, fan noise, and uneven temperature distribution and oscillations can be experienced [54,55].

\subsection{Hydronic Radiant Systems}

Hydronic radiant systems transfer thermal energy by conduction through the component they are installed in (ceiling, floor or wall), by convection between the panel and the air in the space, and by radiation between the panel and the surrounding areas, occupants and objects. They allow spaces to be conditioned very efficiently [56]. Radiant systems provide improved thermal comfort, producing small temperature oscillations and vertical stratification $[57,58]$, while operating at significantly lower temperatures of supply water and thus with lower energy consumption $[54,59,60]$.

Being installed in the floor, ceiling or wall, they take advantage of a larger heat exchanging surface compared to other heating systems. Furthermore, even higher energy savings can be achieved when advanced types of controls are used, which are able to monitor the temperature of the floor, of the indoor and outdoor air in order to regulate the flow and ensure thermal comfort despite variations in weather conditions [61]. A large number of studies found that heating energy consumption was decisively lower in radiant systems (up to nearly 30\%) than in conventional high and medium temperature systems [62-64]. Nevertheless, taking into consideration underfloor systems, they are characterised by a slow response to temperature settings owing to the high thermal inertia, which can result in occupant thermal discomfort if an attentive and smart control system is not adopted [54,61].

Within this background, radiant ceiling panel (RCP) systems are among the most appropriate solutions for healthcare environments. Indeed, optimal indoor air thermohygrometric conditions have to be ensured in hospital patient rooms. RCP systems provide the highest level of thermal comfort, thanks to a privileged transfer by radiation. They prevent vertical stratification of air temperature and radiant temperature asymmetry that could be experienced by patients laying near a window or external wall. Acoustics comfort is ensured by their quiet operation [56,65-70]. Furthermore, unlike air conditioning systems, RCP reduce unwanted air and dust movement to a minimum, thus significantly improving infection control, further increased by the anti-bacterial paint finishes that inhibit the growth of micro-organisms. Considering the current emergency situation due to the novel COVID-19 pandemic, this aspect acquires even higher importance. In addition, being integrated into a suspended ceiling, $\mathrm{RCP}$ are a space saving solution, which improves the usability of spaces, it is simple to install thanks to their standard dimensions and it is fully and easily inspectionable [71-73]. Finally, as already 
reported by the literature about radiant systems mentioned before, they allow to achieve significant energy savings $[74,75]$.

In the present study, the microclimatic conditions in a hospital patient room equipped with an air conditioning system integrated with RCP were monitored during the heating season, uncovering a slight thermal discomfort. Nevertheless, the literature reviewed above extensively demonstrated the high appropriateness of mixed conditioning systems in healthcare facilities, thus suggesting that the issue observed was due to poor system regulation. Experimental data collected in the monitoring campaign were used to calibrate a building model and dynamic building energy simulations were conducted under different inlet air temperatures to identify the most suitable design conditions for thermal comfort improvement. The objective was to prove that mixed conditioning systems-and especially those composed of an air conditioning system integrated with a hydronic radiant system -are the most effective solution for healthcare facilities when a proper regulation is ensured. It was found that the highest advantages are obtained when neutral air is supplied.

\section{Methodology}

The present study was developed into three steps. The first phase (Section 2.2) focused on the collection of in situ measurements of the indoor microclimatic conditions in a patient room during the heating season, over a one-week period in February 2017. In the second stage (Section 2.3) field measurement data were used to calibrate a building energy simulation model. Finally, dynamic building energy simulations of indoor air temperature, $\mathrm{RH}$, predicted mean vote (PMV) and predicted percentage of dissatisfied (PPD) indexes for the patient room were performed, while varying inlet air temperature of the air conditioning system (Section 2.4).

\subsection{Description of the Case Study Analysed}

The analysis was conducted in a two-bed room of the maternity unit at the Maggiore Hospital in Bologna, a 927-bed hospital in Italy. The unit has 35 hospital beds and is composed by two-bed or three-bed rooms. This type of space was chosen as there is a growing attention of scientific literature to ensure compliance with comfort standards in healthcare environments, particularly with vulnerable patients both from a physical and psychological perspective.

The monitored room was located on the first-floor level of the building and had a total volume of $57.7 \mathrm{~m}^{3}$ (5.68 m long per $3.63 \mathrm{~m}$ wide per $2.8 \mathrm{~m}$ ceiling height), with an external wall facing south-west and a window of $3.63 \mathrm{~m}^{2}$ (2.10 $\mathrm{m}$ wide per $1.73 \mathrm{~m}$ height) (Figure 1).

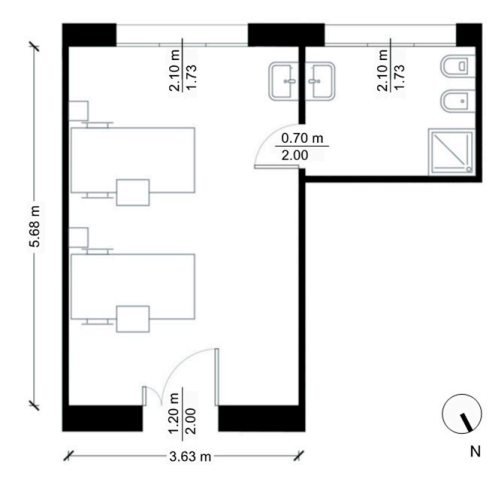

Figure 1. Floor plan of the patient room analysed.

Thermal transmittance of external wall and window was $1.25 \mathrm{~W} / \mathrm{m}^{2} \mathrm{~K}$ and $2.80 \mathrm{~W} / \mathrm{m}^{2} \mathrm{~K}$ respectively. The room was equipped with an air conditioning system integrated with six radiant ceiling panels of $1.8 \mathrm{~m} \times 0.6 \mathrm{~m}$. The hybrid system is designed to provide an airflow rate of $120 \mathrm{~m}^{3} / \mathrm{h}$ (ensured by the constant air volume system) and maintain an indoor air temperature of $22{ }^{\circ} \mathrm{C}$ in winter and $26{ }^{\circ} \mathrm{C}$ in summer, with a relative humidity of $45 \%$. 


\subsection{Monitoring}

Indoor microclimatic conditions were monitored during the heating season, over a one-week period in February 2017. A limited time interval was chosen to avoid interruption or delays of medical activities.

During this period, measurements of outdoor and indoor air temperature, $\mathrm{RH}$, temperature of the room surfaces (window, walls, ceiling and radiant panels) and of inlet air and water, together with inlet water flow rate, were collected. Furthermore, questionnaires were distributed to assess patient thermal comfort.

The type and model of sensors, reported in Table 1, were chosen on the basis of the specific needs of hospital environments, to ensure non-invasive measurements and rapid data downloading.

Table 1. Type, model and accuracy of sensors used in the monitoring campaign.

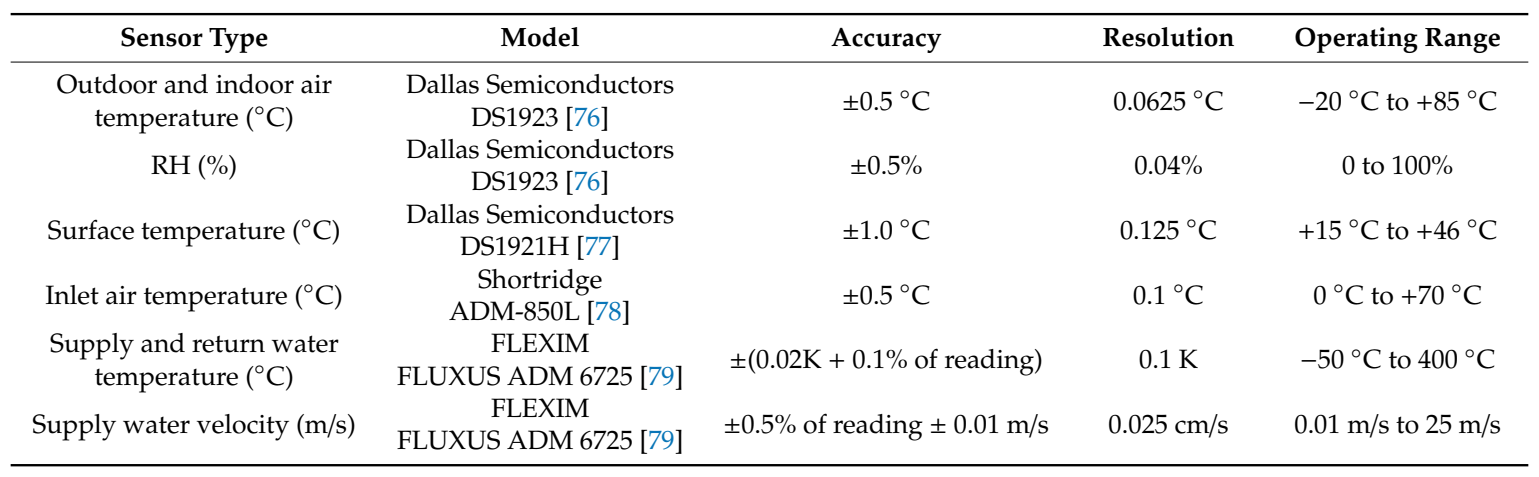

Outdoor and indoor air temperature and RH were measured using iButton Hygrochron Temperature/Humidity Loggers (Dallas Semiconductors, Maxim Integrated, Dallas, TX, USA) [76], while high-resolution Thermochron iButton devices (Dallas Semiconductors, Maxim Integrated, Dallas, TX, USA) [77] were employed for indoor surface temperatures. Measurements of inlet air temperature were carried out through an AirData Multimeter (Shortridge Instruments, Scottsdale, AZ, USA) [78], supply water temperature and flow rate were measured using a portable ultrasonic flowmeter (FLEXIM) [79]. Sensors calibration was carried out at the laboratories of the Department of Industrial Engineering of the University of Bologna, Bologna, Italy.

Measurements were collected every five minutes from 2 February to 9 February 2017; about 2000 pieces of data were registered for each monitored position, for a total of 34,272 measurements.

To determine the number and position of the measuring points, reported in Figure 2, an extensive preliminary survey was conducted using iButton devices and an infrared thermal camera (ThermaCAM PM675, FLIR Systems, Wilsonville, OR, USA) [80].

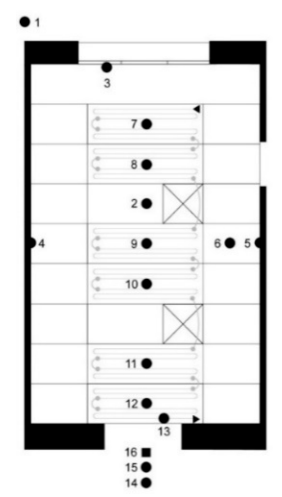

Figure 2. Position of the measuring points. 
Experimental data collected during the monitoring campaign underlined a problem in thermal comfort control for patients and staff. As shown in Table 2, in situ measurements indicate that the average indoor air temperature was about $24.4{ }^{\circ} \mathrm{C}$, with a mean $\mathrm{RH}$ of $37 \%$.

Table 2. In situ measurements from 2 February to 9 February 2017.

\begin{tabular}{cccc}
\hline Measuring Point & Parameter & Min & Max \\
\hline 1 & Outdoor air temperature $\left({ }^{\circ} \mathrm{C}\right)$ & 2.6 & 22.8 \\
2 & Indoor air temperature $\left({ }^{\circ} \mathrm{C}\right)$ & 22.7 & 26.2 \\
2 & $\mathrm{RH}(\%)$ & $27 \%$ & $57 \%$ \\
3 & Window surface temperature (internal) $\left({ }^{\circ} \mathrm{C}\right)$ & 15.6 & \\
4 & Left wall surface temperature $\left({ }^{\circ} \mathrm{C}\right)$ & 22.6 & 25.2 \\
5 & Right wall surface temperature $\left({ }^{\circ} \mathrm{C}\right)$ & 22.4 & 24.7 \\
6 & Inactive ceiling panel temperature $\left({ }^{\circ} \mathrm{C}\right)$ & 22.7 & 25.7 \\
7 & Active radiant panel 1 temperature $\left({ }^{\circ} \mathrm{C}\right)$ & 22.1 & 32.8 \\
8 & Active radiant panel 2 temperature $\left({ }^{\circ} \mathrm{C}\right)$ & 22.4 & 32.0 \\
9 & Active radiant panel 3 temperature $\left({ }^{\circ} \mathrm{C}\right)$ & 22.7 & 31.4 \\
10 & Active radiant panel 4 temperature $\left({ }^{\circ} \mathrm{C}\right)$ & 22.4 & 30.6 \\
11 & Active radiant panel 5 temperature $\left({ }^{\circ} \mathrm{C}\right)$ & 23.5 & 30.0 \\
12 & Active radiant panel 6 temperature $\left({ }^{\circ} \mathrm{C}\right)$ & 22.8 & 29.2 \\
13 & Inlet air temperature $\left({ }^{\circ} \mathrm{C}\right)$ & 23.2 & 25.2 \\
14 & Supply water temperature $\left({ }^{\circ} \mathrm{C}\right)$ & 25.4 & 36.0 \\
15 & Return water temperature $\left({ }^{\circ} \mathrm{C}\right)$ & 22.9 & 30.8 \\
16 & Supply water velocity $(\mathrm{m} / \mathrm{s})$ & 0.000 & 0.168 \\
\hline
\end{tabular}

Moreover, results from the questionnaires distributed to patients revealed a perception of "dry air" and a moderate feeling of warmth, equal to a PMV value of +1 [81], therefore slightly above the recommended acceptable PMV range for thermal comfort defined by EN-ISO 7730 [82] and ASHRAE Standard 55-2013 [83], which is between -0.5 and +0.5 .

\subsection{Calibration of the Building Simulation Model}

Data collected over four days of the monitoring period, from 2 February to 5 February 2017, were used to calibrate a building energy model in TRNSYS, a dynamic building energy simulation program $[84,85]$.

For the calibration process, plant systems information and all the other parameters that had been obtained from the experimental campaign were entered in Simulation Studio in order to populate the model. Regarding weather data, measurements carried out through sensor n.1 (Figure 2) were employed to provide the model with outdoor air temperature distribution, whilst data recorded by the weather station of the University of Bologna, located $1 \mathrm{~km}$ far from the hospital, were used for solar radiation and the other parameters.

The geometric model of the building hosting the maternity unit was generated with Google SketchUp plug-in. Walls, floor, ceiling, and window in the room were modelled according to the real characteristics described in Section 2.1. A view of the 3D model of the entire building and a focus on the patient room under investigation are illustrated in Figure 3.

The room ceiling is divided into 11 rectangular modules. Six of them, identified with a number ranging from 1 to 6 , represent active radiant panels while the other five ones are non-active panels. Hot water flowing inside the radiant panels enters in panel n.1 and exit from panel n.6.

Input data for the first active radiant panel were provided by in situ measurements of supply water temperature and flow rate entering panel n.1 collected during the monitoring period. When the $\mathrm{RCP}$ were operating, the average supply water temperature was $32.7^{\circ} \mathrm{C}\left(\min 29^{\circ} \mathrm{C}\right.$, $\left.\max 35.5^{\circ} \mathrm{C}\right)$ whilst mass flow rate was about $90 \mathrm{~kg} / \mathrm{h}(\min 79 \mathrm{~kg} / \mathrm{h}$, $\max 102 \mathrm{~kg} / \mathrm{h})$. 


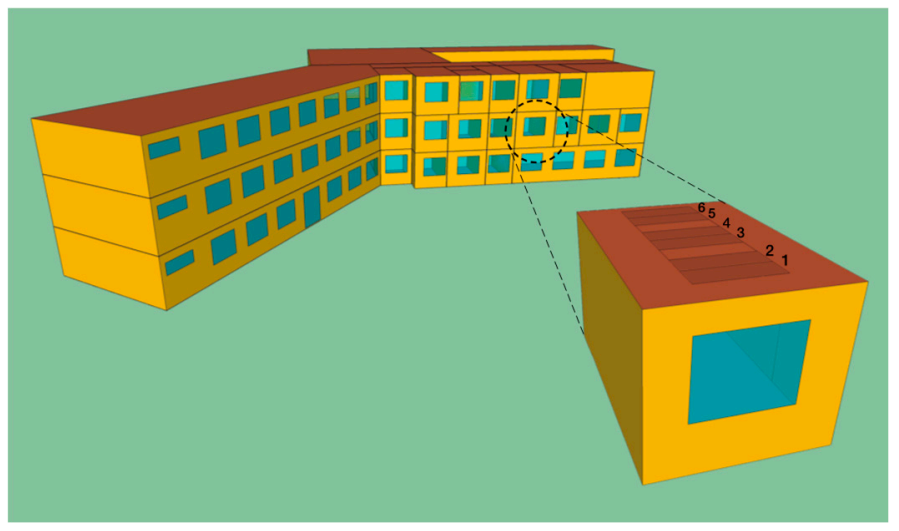

Figure 3. View of the maternity unit building and focus on the patient room analysed.

Similarly, in the calibration process inlet air was supplied under the same conditions (temperature and mass flow rate) that had been measured in the experimental campaign. The average inlet air temperature was $24.4{ }^{\circ} \mathrm{C}$, with a constant flow rate of $120 \mathrm{~m}^{3} / \mathrm{h}$. The inlet was positioned $0.5 \mathrm{~m}$ over the entrance door.

Building envelope and internal gains were entered in TRNBuild package $[84,85]$. Regarding heat gains from occupants, a variable number of people was considered. During the monitoring two patients usually occupied the room, the presence of some visitors was also observed. The occupancy schedule used for the model calibration is reported in Table 3.

Table 3. Occupancy schedule of the patient room defined on the basis of visiting hours.

\begin{tabular}{ccc}
\hline From & Until & People \\
\hline $00: 00$ & $06: 30$ & 2 \\
$06: 30$ & $08: 30$ & 3 \\
$08: 30$ & $12: 30$ & 2 \\
$12: 30$ & $14: 30$ & 3 \\
$14: 30$ & $18: 30$ & 2 \\
$18: 30$ & $20: 30$ & 4 \\
$20: 30$ & $24: 00$ & 2 \\
\hline
\end{tabular}

Furthermore, a patient metabolic rate equal to 0.7 met was assumed, whist 1 met was the value supposed for visitors. The parameters measured during the monitoring campaign and the other input data used to calibrate the model are reported in Table 4.

Table 4. Input data utilised for building model calibration.

\begin{tabular}{ccc}
\hline Input Data & Value & Element Informed \\
\hline outdoor air temperature $\left({ }^{\circ} \mathrm{C}\right)$ & field measurements & heating coil (type 754), building (type 56) \\
heating coil (type 754$)$ & field measurements \\
inlet air temperature $\left({ }^{\circ} \mathrm{C}\right)$ & field measurements & first radiant panel (type 56) \\
supply water temperature $\left({ }^{\circ} \mathrm{C}\right)$ & field measurements & internal heat gains (type 56) \\
water flow rate $(\mathrm{kg} / \mathrm{s})$ & 80 & internal heat gains (type 56) \\
internal heat gains (type 56) \\
total heat gain from artificial lighting $\left(\mathrm{W} / \mathrm{m}^{2}\right)$ & 0.7 & internal heat gains (type 56) \\
internal heat gains (type 56) \\
power of medical monitoring equipment $(\mathrm{W})$
\end{tabular}


After having populated the model with as-built fabric, building plant systems, internal heat gains and occupancy values, a series of dynamic simulations were conducted to further refine the model, in a reiterative process of incremental adjustments to eventually define the final calibrated version. Simulation results of the final calibrated version of the building model were eventually compared to the data collected from 2 to 5 February 2017, the monitored period chosen for calibration. In Figures 4 and 5, the simulated indoor air temperature and mean surface temperatures of the six active radiant panels were plotted against the measured ones.

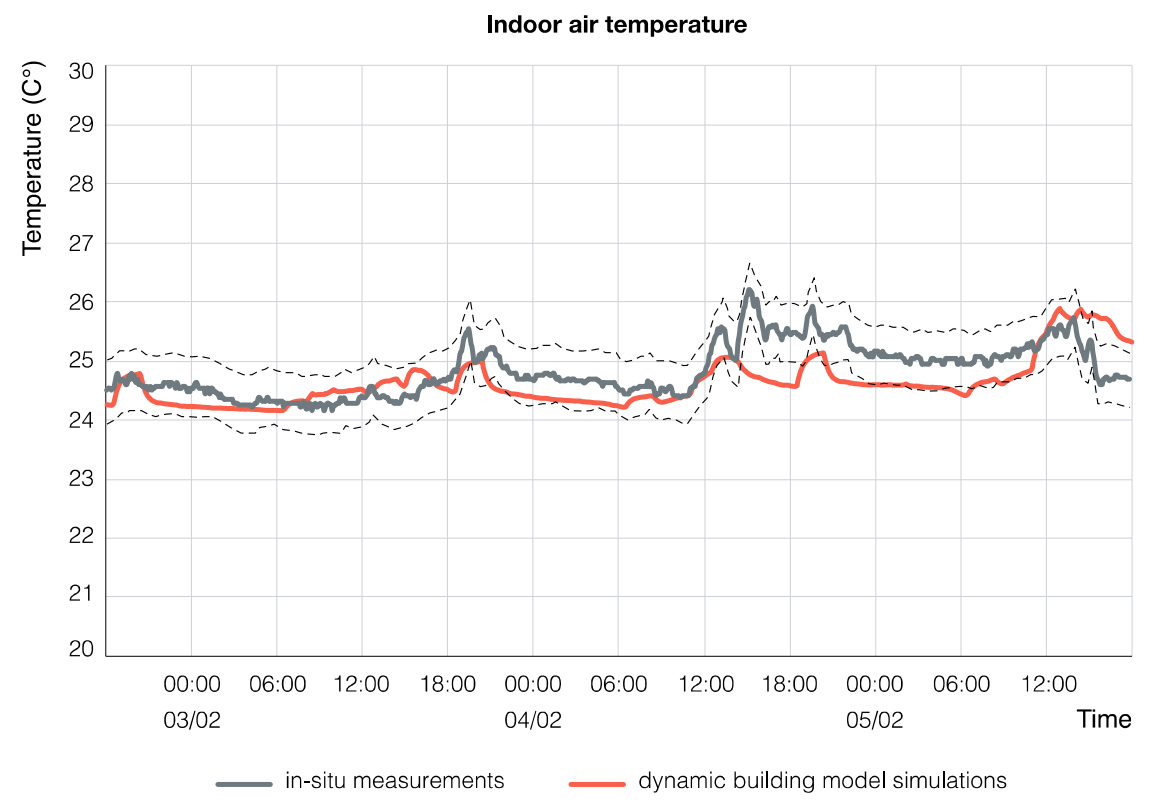

Figure 4. Simulated and monitored indoor air temperatures from 2 to 5 February 2017. The dashed curves represent the band $\pm 0.5^{\circ} \mathrm{C}$ of the measured values.

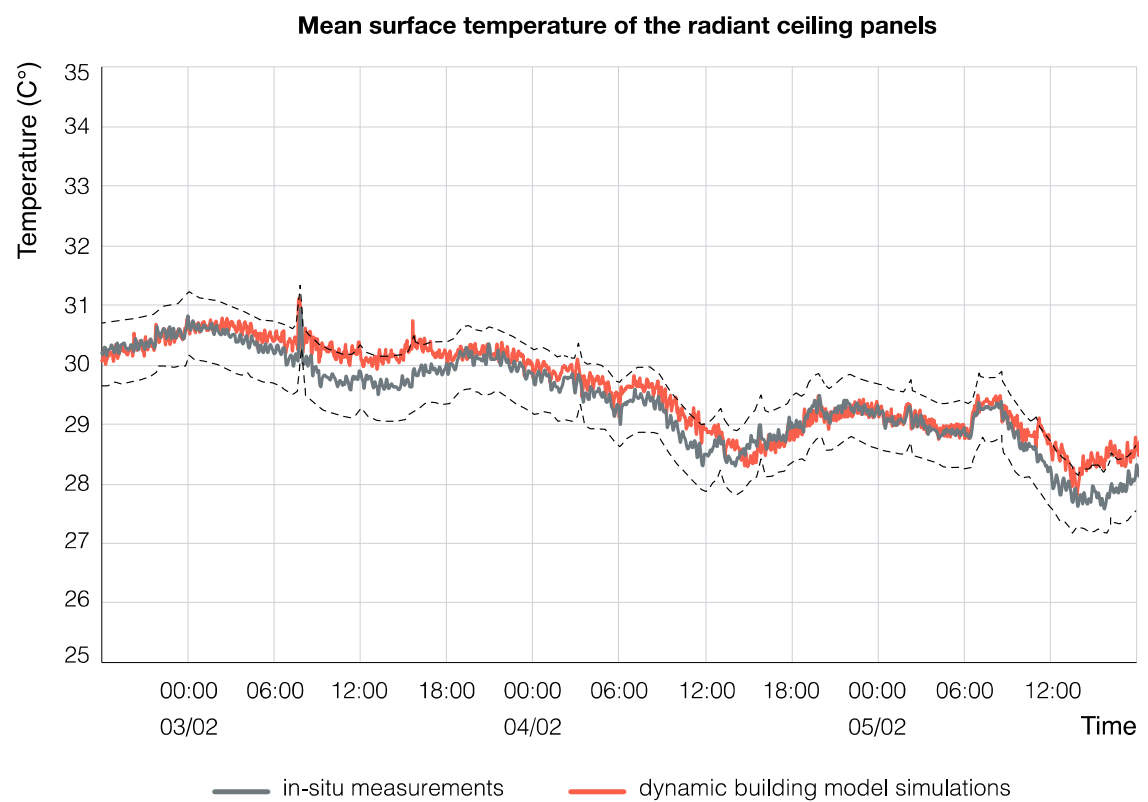

Figure 5. Simulated and monitored mean surface temperatures of the active radiant panels from 2 to 5 February 2017. The dashed curves represent the band $\pm 0.5^{\circ} \mathrm{C}$ of the measured values.

The grey line reports the values gathered from in situ measurements. Two dashed lines plotted with an offset of $\pm 0.5{ }^{\circ} \mathrm{C}$ above and below the grey line represent the sensor accuracy (Table 1) 
employed for the measurement of indoor air temperature. The temperature distributions obtained from simulations are outlined by the reddish line.

In order to aid a more comprehensive understanding of the results obtained and depicted in the charts, the percentage of time during which the simulated values of temperature fall within the area delimited by the dashed lines was calculated. It was found that simulation results for indoor air temperature were included between the dashed lines $81 \%$ of the time (Figure 4 ), while simulated mean surface temperature distribution on the RCP fell within the depicted range $93 \%$ of the time (Figure 5). The values of indoor air and mean surface temperature obtained from simulations were also evaluated considering an offset of $\pm 1^{\circ} \mathrm{C}$ from the measured data. It was observed that the simulated mean surface temperature was inside the $\pm 1{ }^{\circ} \mathrm{C}$ band for $100 \%$ of the time, whilst indoor air temperature was within the range for $96 \%$ of the time. The percentages obtained underline that, while the comparison between the monitored and simulated surface temperatures of the radiant panels shows a good agreement (Figure 5), the correlation between measured and simulated indoor air temperatures reports a slight discrepancy in the data (Figure 4). Likely, this could be related to the variation in internal heat gains associated to the presence of people. Indeed, whilst for the other parameters used in the model calibration the actually measured values were employed, this parameter was defined in the building simulation model according to a standard occupancy schedule (Table 3). We did not have the exact number of mets for each visitor, as well as we could not know if and when a patient had gone out from the room to make some analysis, or if and when (for a short period of time) a large number of visitors, physicians or medical staff had entered the room and had turned all the lights on. For this reason, internal heat gains associated to the presence of people may actually vary, thus remaining a variable difficult to predict with precision. However, the analysis done from the observation of the bands $\pm 0.5^{\circ} \mathrm{C}$ and $\pm 1{ }^{\circ} \mathrm{C}$ shows how internal gains are not so of a pivotal importance in the temperature simulation.

\subsection{Dynamic Building Energy Simulations}

The calibrated building model was used to perform a series of dynamic building energy simulations under different inlet air temperatures, with the purpose of improving energy efficiency and occupant thermal comfort. Simulations were carried out for the whole heating period, from October to April, with the same software tool as the one used for the model calibration, TRNSYS. The climatic data of the Typical Meteorological Year (TMY) defined by Meteonorm for Bologna and reported in the external text files read by Simulation Studio were used [84,85]. Operating hours of the RCP, indoor air temperature, RH, PMV and PPD indexes were analysed. More in detail, PMV and PPD were evaluated for two points in the room, bed A and bed B, illustrated in Figure 6.

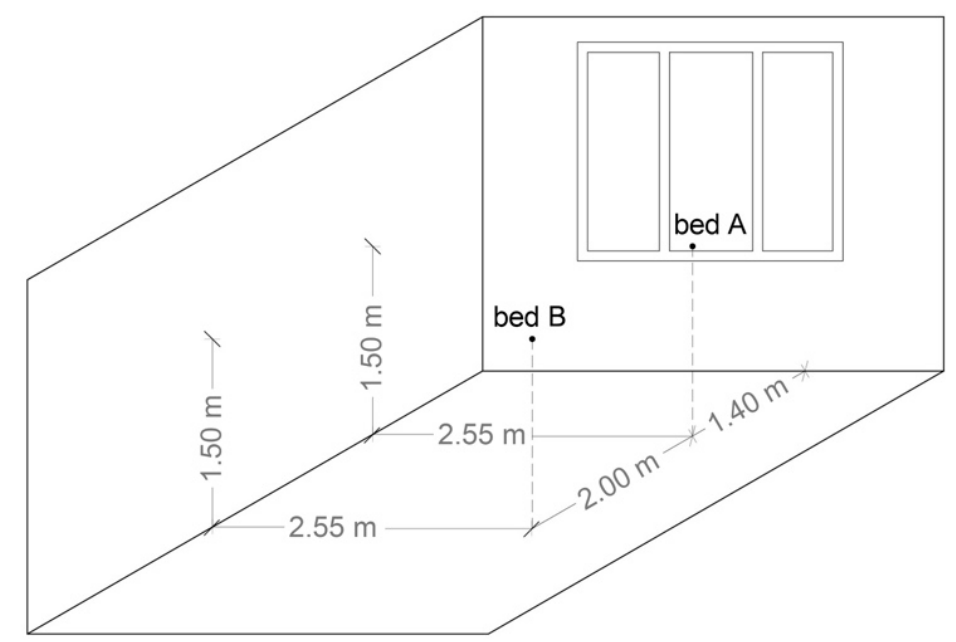

Figure 6. Position of the two points for which PMV and PPD indexes were evaluated. 
Five different conditions for inlet air temperature were investigated: $20^{\circ} \mathrm{C}, 21^{\circ} \mathrm{C}, 22^{\circ} \mathrm{C}, 23^{\circ} \mathrm{C}$ and $24^{\circ} \mathrm{C}$. Furthermore, supply water temperature $\left(T_{s w}\right)$ to the RCP was defined according to outdoor air temperature $\left(T_{\text {ext }}\right)$, on the basis of the following equation, Equation (1):

$$
T_{s w}=37-0.6 \cdot T_{\text {ext }}
$$

Heating set point temperature was $22^{\circ} \mathrm{C}$ and thermal resistance of occupants' clothing (clo) was assumed to be $1[83,86,87]$, with an average air speed of $0.1 \mathrm{~m} / \mathrm{s}$. Dynamic simulations were conducted with a time step of five minutes, the same time interval according to which measurement data were recorded during the monitoring campaign.

\section{Results}

The results obtained from simulations, and reported in Tables 5-9, were processed both on a yearly and on a monthly basis and further analysed under two perspectives, when the radiant panels were turned on and when they turned themselves off, due to the contribution of internal heat gains.

Table 5. Monthly RCP operating hours, mean indoor air temperature, RH, PMV and PPD with inlet air temperature of $20^{\circ} \mathrm{C}$.

\begin{tabular}{|c|c|c|c|c|c|c|c|}
\hline \multicolumn{8}{|c|}{ Inlet Air Temperature $20^{\circ} \mathrm{C}$} \\
\hline October & - & 24.5 & 48.9 & +0.54 & +0.56 & 12.96 & 13.30 \\
\hline RCP ON mode & 0 & - & - & - & - & - & - \\
\hline RCP ON mode & 392 & 22.2 & 50.1 & -0.08 & -0.04 & 5.16 & 5.06 \\
\hline RCP OFF mode & 328 & 22.6 & 50.5 & +0.01 & +0.04 & 5.36 & 5.35 \\
\hline December & - & 22.1 & 49.1 & -0.10 & -0.06 & 5.39 & 5.22 \\
\hline RCP ON mode & 604 & 22.0 & 49.3 & -0.13 & -0.08 & 5.38 & 5.17 \\
\hline RCP OFF mode & 140 & 22.6 & 48.0 & +0.01 & +0.05 & 5.44 & 5.44 \\
\hline RCP ON mode & 505 & 22.1 & 48.9 & -0.10 & -0.05 & 5.24 & 5.09 \\
\hline RCP OFF mode & 167 & 22.7 & 47.8 & +0.02 & +0.05 & 5.42 & 5.41 \\
\hline March & - & 22.7 & 48.1 & +0.03 & +0.06 & 5.43 & 5.44 \\
\hline RCP ON mode & 172 & 22.3 & 48.6 & -0.06 & -0.02 & 5.11 & 5.04 \\
\hline RCP OFF mode & 572 & 22.8 & 47.9 & +0.06 & +0.09 & 5.53 & 5.56 \\
\hline April & - & 24.0 & 48.3 & +0.39 & +0.41 & 10.49 & 10.71 \\
\hline RCP ON mode & 43 & 22.3 & 49.5 & -0.06 & -0.03 & 5.10 & 5.03 \\
\hline RCP OFF mode & 677 & 24.1 & 48.2 & +0.42 & +0.44 & 10.83 & 11.07 \\
\hline
\end{tabular}


Table 6. Monthly RCP operating hours, mean indoor air temperature, RH, PMV and PPD with inlet air temperature of $21^{\circ} \mathrm{C}$.

\begin{tabular}{|c|c|c|c|c|c|c|c|}
\hline \multicolumn{8}{|c|}{ Inlet Air Temperature $21^{\circ} \mathrm{C}$} \\
\hline $\begin{array}{c}\text { Month } \\
\& \\
\text { RCP Mode }\end{array}$ & $\begin{array}{c}\text { RCP } \\
\text { Operating Hours } \\
\text { (h) }\end{array}$ & $\begin{array}{c}\text { Mean Indoor Air } \\
\text { Temperature } \\
\left({ }^{\circ} \mathrm{C}\right)\end{array}$ & $\begin{array}{c}\text { Mean } \\
\text { RH } \\
(\%)\end{array}$ & $\begin{array}{l}\text { Mean } \\
\text { PMV } \\
\text { Bed A }\end{array}$ & $\begin{array}{l}\text { Mean } \\
\text { PMV } \\
\text { Bed B }\end{array}$ & $\begin{array}{l}\text { Mean } \\
\text { PPD } \\
\text { Bed A }\end{array}$ & $\begin{array}{l}\text { Mean } \\
\text { PPD } \\
\text { Bed B }\end{array}$ \\
\hline October & - & 24.8 & 49.4 & +0.60 & +0.62 & 14.27 & 14.68 \\
\hline RCP ON mode & 0 & - & - & - & - & - & - \\
\hline RCP OFF mode & 744 & 24.8 & 49.4 & +0.60 & +0.62 & 14.27 & 14.68 \\
\hline November & - & 22.5 & 52.1 & -0.01 & +0.02 & 5.26 & 5.23 \\
\hline RCP ON mode & 296 & 22.3 & 51.6 & -0.06 & -0.02 & 5.09 & 5.02 \\
\hline RCP OFF mode & 424 & 22.6 & 52.4 & +0.02 & +0.05 & 5.37 & 5.38 \\
\hline December & - & 22.3 & 51.1 & -0.06 & -0.01 & 5.24 & 5.15 \\
\hline RCP ON mode & 554 & 22.2 & 51.4 & -0.08 & -0.04 & 5.17 & 5.05 \\
\hline RCP OFF mode & 190 & 22.6 & 50.5 & +0.01 & +0.05 & 5.45 & 5.46 \\
\hline January & - & 22.4 & 50.7 & -0.05 & +0.00 & 5.25 & 5.19 \\
\hline RCP ON mode & 522 & 22.2 & 50.9 & -0.08 & -0.02 & 5.15 & 5.04 \\
\hline RCP OFF mode & 222 & 22.7 & 50.0 & +0.03 & +0.07 & 5.49 & 5.53 \\
\hline February & - & 22.4 & 50.9 & -0.04 & +0.00 & 5.23 & 5.17 \\
\hline RCP ON mode & 424 & 22.2 & 51.0 & -0.07 & -0.02 & 5.13 & 5.03 \\
\hline RCP OFF mode & 248 & 22.6 & 50.6 & +0.00 & +0.04 & 5.41 & 5.39 \\
\hline March & - & 22.9 & 50.0 & +0.07 & +0.10 & 5.61 & 5.66 \\
\hline RCP ON mode & 116 & 22.3 & 50.8 & -0.05 & -0.01 & 5.07 & 5.02 \\
\hline RCP OFF mode & 628 & 23.0 & 49.8 & +0.10 & +0.12 & 5.71 & 5.78 \\
\hline April & - & 24.2 & 48.9 & +0.44 & +0.46 & 11.45 & 11.73 \\
\hline RCP ON mode & 27 & 22.3 & 51.4 & -0.05 & -0.01 & 5.06 & 5.01 \\
\hline RCP OFF mode & 693 & 24.3 & 48.8 & +0.46 & +0.48 & 11.70 & 11.99 \\
\hline
\end{tabular}

Table 7. Monthly RCP operating hours, mean indoor air temperature, RH, PMV and PPD with inlet air temperature of $22{ }^{\circ} \mathrm{C}$.

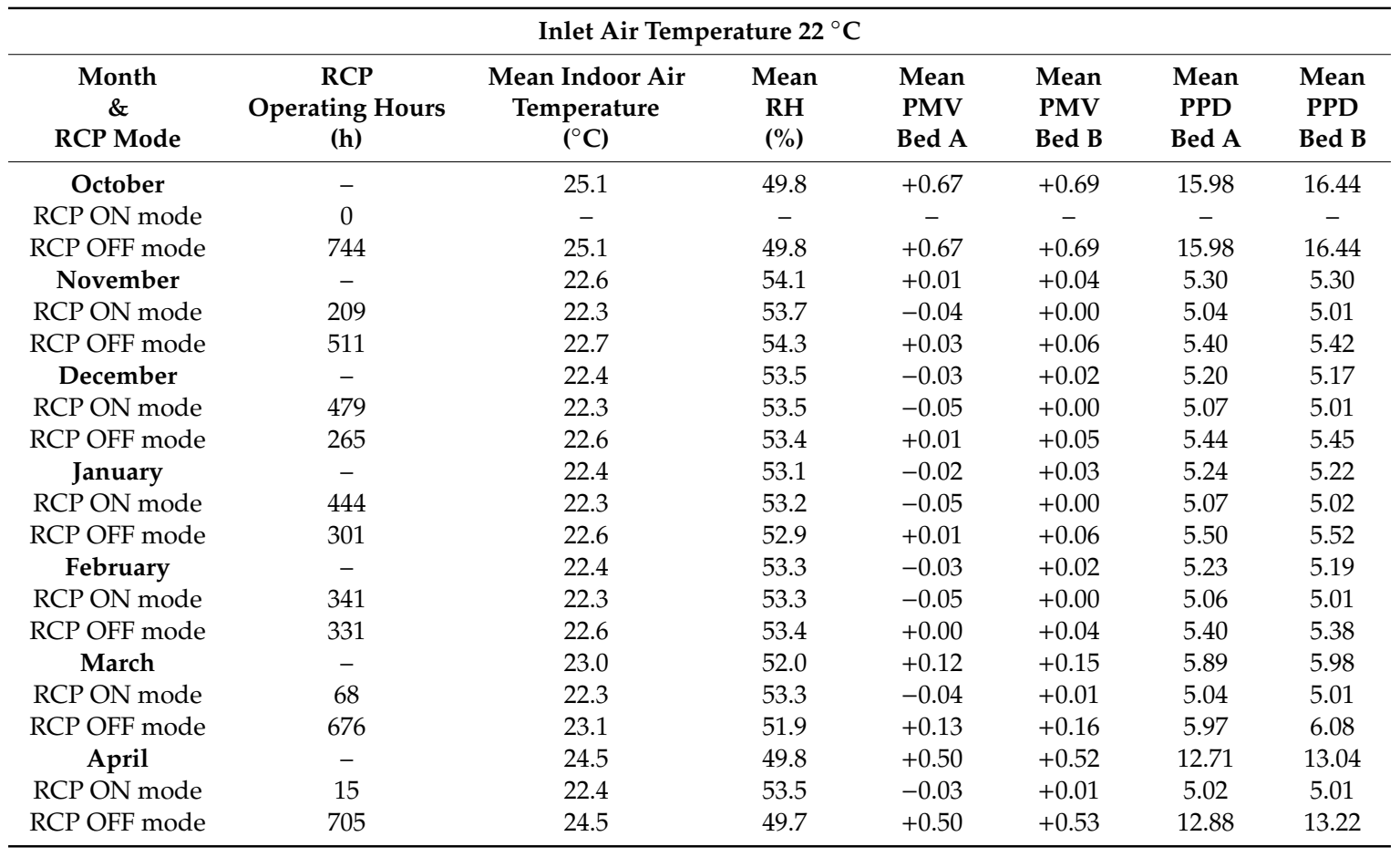


Table 8. Monthly RCP operating hours, mean indoor air temperature, RH, PMV and PPD with inlet air temperature of $23^{\circ} \mathrm{C}$.

\begin{tabular}{|c|c|c|c|c|c|c|c|}
\hline \multicolumn{8}{|c|}{ Inlet Air Temperature $23^{\circ} \mathrm{C}$} \\
\hline $\begin{array}{c}\text { Month } \\
\& \\
\text { RCP Mode }\end{array}$ & $\begin{array}{c}\text { RCP } \\
\text { Operating Hours } \\
\text { (h) }\end{array}$ & $\begin{array}{c}\text { Mean Indoor Air } \\
\text { Temperature } \\
\left({ }^{\circ} \mathrm{C}\right)\end{array}$ & $\begin{array}{c}\text { Mean } \\
\text { RH } \\
(\%)\end{array}$ & $\begin{array}{l}\text { Mean } \\
\text { PMV } \\
\text { Bed A }\end{array}$ & $\begin{array}{l}\text { Mean } \\
\text { PMV } \\
\text { Bed B }\end{array}$ & $\begin{array}{l}\text { Mean } \\
\text { PPD } \\
\text { Bed A }\end{array}$ & $\begin{array}{l}\text { Mean } \\
\text { PPD } \\
\text { Bed B }\end{array}$ \\
\hline October & - & 25.4 & 50.4 & +0.74 & +0.76 & 18.25 & 18.80 \\
\hline RCP ON mode & 0 & - & - & - & - & - & - \\
\hline RCP OFF mode & 744 & 25.4 & 50.4 & +0.74 & +0.76 & 18.25 & 18.80 \\
\hline November & - & 22.7 & 56.4 & +0.03 & +0.07 & 5.38 & 5.41 \\
\hline RCP ON mode & 134 & 22.4 & 56.3 & -0.02 & +0.02 & 5.02 & 5.02 \\
\hline RCP OFF mode & 586 & 22.7 & 56.4 & +0.04 & +0.08 & 5.46 & 5.50 \\
\hline December & - & 22.5 & 56.0 & -0.01 & +0.03 & 5.24 & 5.24 \\
\hline RCP ON mode & 386 & 22.4 & 55.9 & -0.03 & +0.02 & 5.03 & 5.02 \\
\hline RCP OFF mode & 358 & 22.6 & 56.2 & +0.01 & +0.05 & 5.46 & 5.47 \\
\hline January & - & 22.5 & 55.7 & -0.01 & +0.04 & 5.27 & 5.28 \\
\hline RCP ON mode & 361 & 22.3 & 55.7 & -0.03 & +0.02 & 5.03 & 5.02 \\
\hline RCP OFF mode & 383 & 22.6 & 55.7 & +0.01 & +0.06 & 5.50 & 5.52 \\
\hline February & - & 22.5 & 55.9 & -0.01 & +0.04 & 5.26 & 5.25 \\
\hline RCP ON mode & 267 & 22.4 & 55.7 & -0.03 & +0.02 & 5.02 & 5.02 \\
\hline RCP OFF mode & 405 & 22.6 & 56.0 & +0.00 & +0.04 & 5.41 & 5.41 \\
\hline March & - & 23.2 & 54.1 & +0.16 & +0.19 & 6.29 & 6.44 \\
\hline RCP ON mode & 36 & 22.4 & 55.9 & -0.02 & +0.02 & 5.02 & 5.02 \\
\hline RCP OFF mode & 708 & 23.2 & 54.0 & +0.17 & +0.20 & 6.35 & 6.51 \\
\hline April & - & 24.8 & 50.9 & +0.57 & +0.59 & 14.39 & 14.79 \\
\hline RCP ON mode & 6 & 22.4 & 56.3 & -0.02 & +0.02 & 5.02 & 5.02 \\
\hline RCP OFF mode & 714 & 24.8 & 50.8 & +0.58 & +0.60 & 14.47 & 14.88 \\
\hline
\end{tabular}

Table 9. Monthly RCP operating hours, mean indoor air temperature, RH, PMV and PPD with inlet air temperature of $24{ }^{\circ} \mathrm{C}$.

\begin{tabular}{|c|c|c|c|c|c|c|c|}
\hline \multicolumn{8}{|c|}{ Inlet Air Temperature $24^{\circ} \mathrm{C}$} \\
\hline October & - & 25.7 & 51.2 & +0.83 & +0.85 & 21.06 & 21.72 \\
\hline RCP ON mode & 0 & - & - & - & - & - & - \\
\hline RCP ON mode & 76 & 22.4 & 59.1 & -0.01 & +0.03 & 5.01 & 5.03 \\
\hline RCP OFF mode & 644 & 22.8 & 58.7 & +0.07 & +0.11 & 5.57 & 5.65 \\
\hline December & - & 22.5 & 58.9 & +0.00 & +0.04 & 5.30 & 5.31 \\
\hline RCP ON mode & 287 & 22.4 & 58.6 & -0.01 & +0.04 & 5.01 & 5.04 \\
\hline RCP OFF mode & 457 & 22.6 & 59.1 & +0.00 & +0.05 & 5.48 & 5.49 \\
\hline RCP ON mode & 190 & 22.4 & 58.5 & -0.01 & +0.04 & 5.01 & 5.04 \\
\hline RCP OFF mode & 483 & 22.6 & 58.8 & +0.01 & +0.05 & 5.44 & 5.45 \\
\hline March & - & 23.4 & 56.2 & +0.22 & +0.25 & 6.86 & 7.08 \\
\hline RCP ON mode & 16 & 22.4 & 58.8 & -0.01 & +0.03 & 5.01 & 5.03 \\
\hline RCP OFF mode & 728 & 23.4 & 56.2 & +0.23 & +0.26 & 6.90 & 7.12 \\
\hline April & - & 25.1 & 52.2 & +0.65 & +0.67 & 16.59 & 17.09 \\
\hline RCP ON mode & 0 & - & - & - & - & - & - \\
\hline RCP OFF mode & 720 & 25.7 & 52.2 & +0.83 & +0.85 & 21.05 & 21.71 \\
\hline
\end{tabular}

The analysis of the data on a yearly basis showed a decrease in the RCP operating hours for increasing inlet air temperatures. RCP operating hours ranged from $2290 \mathrm{~h}$ when inlet air temperature was equal to $20^{\circ} \mathrm{C}$, to $1940 \mathrm{~h}$ for $21^{\circ} \mathrm{C}, 1555 \mathrm{~h}$ for $22^{\circ} \mathrm{C}, 1190 \mathrm{~h}$ for $23^{\circ} \mathrm{C}$, lowering up to $842 \mathrm{~h}$ for an inlet air temperature of $24^{\circ} \mathrm{C}$. 
A first analysis of the monthly data regarding the PMV showed that the best thermal comfort control, represented by a PMV $=0$, was achieved when indoor air temperature was about $22.3^{\circ} \mathrm{C}$. A slight thermal discomfort due to a moderate feeling of warmth, equal to a PMV $>+0.1$, was perceived when indoor air temperature reached a value of about $23^{\circ} \mathrm{C}$, while a rare moderate feeling of cold, represented by a PMV $<-0.1$, arose when indoor air temperature was about $22^{\circ} \mathrm{C}$.

A comparative analysis of the results under the different inlet air temperatures showed that the best thermal comfort was obtained when neutral air was supplied, therefore with an inlet air temperature of $22{ }^{\circ} \mathrm{C}$ (Table 7). Indeed, under this scenario a PMV value equal to 0 was more frequently reached and the lowest values for PPD were achieved. Furthermore, this is the condition that ensured the lowest PMV discrepancy between the RCP ON mode and OFF mode. The mean RH was about $52.2 \%$

For a comprehensive interpretation of the data obtained from simulations it is also necessary to underline that, comparing PMV index achieved during the different months, a more important discomfort was perceived in October, and, to a lesser extent, in April when radiant panels turned themselves off. This negative result is due to the fact that the condition for PMV evaluation, or rather thermal resistance of occupants' clothing, was not varied throughout the simulation period. Conversely, a lowest value of clo should be used for the months just at the beginning and at the end of the heating period, when indoor air temperature reaches the highest values.

\section{Discussion and Conclusions}

The monitoring campaign conducted in a patient room of the maternity unit of the Maggiore Hospital in Bologna over a one-week period in February 2017 underlined a thermal discomfort related to a moderate feeling of warmth and a perception of "dry air". The problem was reported by in situ measurements of indoor air temperature and $\mathrm{RH}$, reaching a mean value of $24.4{ }^{\circ} \mathrm{C}$ and $37 \%$ respectively, as well as by questionnaires distributed to patients, whose answers were comparable to a PMV value of about +1 . Measured inlet air temperature had an average value of $24.6^{\circ} \mathrm{C}$, while mean water supply temperature was about $27.7^{\circ} \mathrm{C}$. Therefore, the air conditioning system had been operating with a definitely too high inlet air temperature, causing occupant thermal discomfort and uselessly consuming a lot of energy, especially considering the poor quality of the building envelope which dramatically increases heat losses. At the same time, the wrong regulation of the air conditioning system did not exploit RCP and their significantly lower energy consumption. Indeed, due to the already high indoor air temperature, RCP had not been frequently operating.

The results of dynamic building simulations carried out under different inlet air temperatures and regulating water supply temperature on the basis of outdoor air temperature showed that the best thermal comfort was reached when neutral air was supplied, therefore at $22{ }^{\circ} \mathrm{C}$ (Table 7). Under this condition, a PMV index equal to 0 was more frequently achieved over the whole simulation period. The mean indoor air temperature in February varied from 22.3 to $22.6{ }^{\circ} \mathrm{C}$ with a mean $\mathrm{RH}$ ranging from $53.3 \%$ and $53.4 \%$ when RCP were working and when they turned themselves off respectively. The discomfort perceived in October, and to a lesser extent, in April when radiant panels were in OFF mode, suggests a less heavy clothing for patients.

As extensively demonstrated by the studies available in the literature and reviewed in Section 1.1, mixed conditioning systems are the optimal solution in healthcare facilities, as long as a proper regulation of the system is ensured. Healthcare spaces can be efficiently heated/cooled by hydronic radiant systems, which significantly improve thermal comfort while considerably reducing energy consumption thanks to their low supply water temperatures, whereas properly regulated air conditioning systems can be used just to provide IAQ, adequate ventilation and infection control.

The present study demonstrated the high appropriateness of mixed conditioning systems in healthcare facilities, but it underlined the need for the system to be properly regulated at the same time, otherwise occupant thermal discomfort could be experienced. Furthermore, by investigating the most suitable design conditions for thermal comfort improvement, it was found that the best thermal comfort was achieved when neutral air was supplied. The analysis has been focused on the 
investigation of thermal comfort conditions and its achievement. Nevertheless, the reviewed research results and consequently the related energy saving potential underline the importance to concentrate on energy performance evaluation and, more in detail, on the analysis of energy consumption related to the production of hot water for RCP and for the Air Handling Unit (UTA), as well as to investigate the cooling period, in order to build a more robust and comprehensive energy framework.

Moreover, to further improve patient, visitors and staff thermal comfort, one of the future developments of the work is to regulate inlet air temperature according to internal heat gains, thus on the basis of solar radiation or the number of people in the room. However, as this scenario requires providing all patient rooms with a people counting system, and given that inlet air temperature is set by the air handling unit and cannot be varied for each room, the next phase of the study could be focused on the definition of inlet air temperature on the basis of visiting hours.

Author Contributions: Conceptualisation, P.V. and P.R.; methodology, P.V.; software, S.C.; validation, P.V., S.C. and M.C.; formal analysis, S.C.; investigation, P.V.; resources, S.M.; data curation, M.C.; writing-original draft preparation, S.C.; writing - review and editing, P.V. and S.C.; visualization, S.C.; supervision, S.M. and P.R.; project administration, M.C.; funding acquisition, S.M. All authors have read and agreed to the published version of the manuscript.

Funding: This research received no external funding.

Conflicts of Interest: The authors declare no conflict of interest.

\section{References}

1. Buildings Performance Institute Europe (BPIE). Europe's Buildings under the Microscope. A Country-by-Country Review of the Energy Performance of Buildings; Buildings Performance Institute Europe: Brussels, Belgium, 2011.

2. Eckelman, M.J.; Sherman, J. Environmental impacts of the U.S. health care system and effects on public health. PLoS ONE 2016, 11, e0157014. [CrossRef] [PubMed]

3. National Health Service (NHS) Sustainable Development Unit. Sustainable Development Strategy for the NHS, Public Health and Social Care System 2014-2020; Sustainable Development Unit: Cambridge, UK, 2014; Available online: https://www.sduhealth.org.uk/policy-strategy/engagement-resources.aspx (accessed on 16 November 2020).

4. Pichler, P.P.; Jaccard, I.S.; Weisz, U.; Weisz, H. International comparison of health care carbon footprints. Environ. Res. Lett. 2019, 14, 064004. [CrossRef]

5. Papadopoulos, A.M. Energy Efficiency in Hospitals: Historical Development, Trends and Perspectives. In Energy Performance of Buildings; Boemi, S.N., Irulegi, O., Santamouris, M., Eds.; Springer: Cham, Switzerland, 2016; pp. 217-234.

6. Prada, M.; Prada, I.F.; Cristea, M.; Popescu, D.E.; Bungău, C.; Aleya, L.; Bungău, C.C. New solutions to reduce greenhouse gas emissions through energy efficiency of buildings of special importance-Hospitals. Sci. Total Environ. 2020, 718, 137446. [CrossRef]

7. Cesari, S.; Valdiserri, P.; Coccagna, M.; Mazzacane, S. The energy saving potential of wide windows in hospital patient rooms, optimizing the type of glazing and lighting control strategy under different climatic conditions. Energies 2020, 13, 2116. [CrossRef]

8. Cesari, S.; Valdiserri, P.; Coccagna, M.; Mazzacane, S. Energy savings in hospital patient rooms: The role of windows size and glazing properties. Energy Procedia 2018, 148, 1151-1158. [CrossRef]

9. Department of Health. Sustainability in Healthcare. Victoria Department of Health. 2012. Available online: https://www2.health.vic.gov.au/hospitals-and-health-services/planning-infrastructure/sustainability (accessed on 10 October 2020).

10. Kapoor, R.; Kumar, S. Energy Efficiency in Hospitals: Best Practice Guide; USAID, ECO-III Project; International Resource Group: Delhi, India, 2011.

11. Thinate, N.; Wongsapai, W.; Damrongsak, D. Energy performance study in Thailand hospital building. Energy Procedia 2017, 141, 255-259. [CrossRef]

12. Verheyen, J.; Theys, N.; Allonsius, L.; Descamps, F. Thermal comfort of patients: Objective and subjective measurements in patient rooms of a Belgian healthcare facility. Build. Environ. 2011, 46, 1195-1204. [CrossRef]

13. Maroni, M. (Ed.) Ventilation and Indoor Air Quality in Hospitals; Springer: Dordrecht, The Netherlands, 1996. 
14. Buonomano, A.; Calise, F.; Ferruzzi, G.; Palombo, A. Dynamic energy performance analysis: Case study for energy efficiency retrofits of hospital buildings. Energy 2014, 78, 555-572. [CrossRef]

15. Hashiguschi, N.; Hirakawa, M.; Tochihara, Y.; Kaji, Y.; Karaki, C. Effects of setting up of humidifiers on thermal conditions and subjective responses of patients and staff in a hospital during winter. Appl. Ergon. 2008, 39, 158-165. [CrossRef]

16. Hashiguschi, N.; Hirakawa, M.; Tochihara, Y.; Kaji, Y.; Karaki, C. Thermal environment and subjective responses of patients and staff in a hospital during winter. J. Physiol. Anthropol. Appl. Hum. Sci. 2005, 24, 111-115. [CrossRef]

17. Skoog, J.; Johansson, A. Indoor Environment in Hospital Wards-Requirements on Thermal Climate, Air Quality, Light and Color; Chalmers University of Technology: Gothenburg, Sweden, 2002.

18. Nordstrom, K.; Norbäck, D.; Akselsson, R. Subjective indoor air quality in hospitals-The influence of building age, ventilation flow, and personal factors. Indoor Built Environ. 1995, 4, 37-44. [CrossRef]

19. Skoog, J. Relative air humidity in hospital wards - User perception and technical consequences. Indoor Built Environ. 2006, 15, 93-97. [CrossRef]

20. Skoog, J.; Fransson, N.; Jagemar, L. Thermal environment in Swedish hospitals: Summer and winter measurements. Energy Build. 2005, 37, 872-877. [CrossRef]

21. Ozyogurtcu, G.; Mobedi, M.; Ozerdem, B. Economical assessment of different HVAC systems for an operating room: Case study for different Turkish climate regions. Energy Build. 2011, 43, 1536-1543. [CrossRef]

22. Balaras, C.A.; Dascalaki, E.; Gaglia, A. HVAC and indoor thermal conditions in hospital operating rooms. Energy Build. 2007, 39, 454-470. [CrossRef]

23. Liu, C.; Zhou, G.; Li, H. Analysis of thermal environment in a hospital operating room. Energy Build. 2015, 121, 735-742. [CrossRef]

24. Nastase, I.; Croitoru, C.; Vartires, A.; Tataranu, L. Indoor environmental quality in operating rooms: An European standards review with regard to Romanian guidelines. Energy Procedia 2016, 85, 375-382. [CrossRef]

25. Dascalaki, E.G.; Gaglia, A.G.; Balaras, C.A.; Lagoudi, A. Indoor environmental quality in Hellenic hospital operating rooms. Energy Build. 2009, 41, 551-560. [CrossRef]

26. Nastase, I.; Croitoru, C.; Dan, M.; Ursu, I.; Meslem, A. Experimental study for the integration of an innovative air distribution system in operating rooms. Energy Procedia 2017, 112, 613-620. [CrossRef]

27. Lee, S.T.; Liang, C.C.; Chien, T.Y.; Wu, F.J.; Fan, K.C.; Wan, G.H. Effect of ventilation rate on air cleanliness and energy consumption in operation rooms at rest. Environ. Monit. Assess. 2018, 190, 178. [CrossRef]

28. Christiansen, N.; Kaltschmitt, M.; Dzukowski, F.; Isensee, F. Electricity consumption of medical plug loads in hospital laboratories: Identification, evaluation, prediction and verification. Energy Build. 2015, 107, 392-406. [CrossRef]

29. Adamu, Z.A.; Price, A.D.F.; Cook, M.J. Performance evaluation of natural ventilation strategies for hospital wards-A case study of Great Ormond Street Hospital. Build. Environ. 2012, 56, 211-222. [CrossRef]

30. Short, C.A.; Lomas, K.J.; Giridharan, R.; Fair, A.J. Building resilience to overheating into 1960's UK hospital buildings within the constraint of the national carbon reduction target: Adaptive strategies. Build. Environ. 2012, 55, 73-95. [CrossRef]

31. Lomas, K.J.; Giridharan, R. Thermal comfort standards, measured internal temperatures and thermal resilience to climate change of free-running buildings: A case-study of hospital wards. Build. Environ. 2012, 55, 57-72. [CrossRef]

32. Ahmadzadehtalatapeh, M.; Yau, Y.H. The application of heat pipe heat exchangers to improve the air quality and reduce the energy consumption of the air conditioning system in a hospital ward-A full year model simulation. Energy Build. 2011, 43, 2344-2355. [CrossRef]

33. Christiansen, N.; Kaltschmitt, M.; Dzukowski, F. Electrical energy consumption and utilization time analysis of hospital departments and large scale medical equipment. Energy Build. 2016, 131, 172-183. [CrossRef]

34. Short, C.A.; Giridharan, R.; Lomas, K.J. A medium-rise 1970s maternity hospital in the east of England: Resilience and adaptation to climate change. Build. Serv. Eng. Res. Technol. 2015, 36, 247-274. [CrossRef]

35. Morgenstern, P.; Li, M.; Raslan, R.; Ruyssevelt, P.; Wright, A. Benchmarking acute hospitals: Composite electricity targets based on departmental consumption intensities? Energy Build. 2016, 118, 277-290. [CrossRef] 
36. Iddon, C.R.; Mills, T.C.; Giridharan, R.; Lomas, K.J. The influence of hospital ward design on resilience to heat waves: An exploration using distributed lag models. Energy Build. 2015, 86, 573-588. [CrossRef]

37. ENERGY STAR. Healthcare: An Overview of Energy Use and Energy Efficiency Opportunities. Available online: https://www.energystar.gov/ia/partners/publications/pubdocs/Healthcare.pdf (accessed on 10 October 2020).

38. Kljajić, M.; Anđelković, A.S.; Mujan, I. Assessment of relevance of different effects in energy infrastructure revitalization in non-residential buildings. Energy Build. 2016, 116, 684-693. [CrossRef]

39. Principi, P.; Fioretti, R.; Carbonari, A.; Lemma, M. Evaluation of energy conservation opportunities through Energy Performance Contracting: A case study in Italy. Energy Build. 2016, 128, 886-899. [CrossRef]

40. Vanhoudt, D.; Desmedt, J.; Van Bael, J.; Robeyn, N.; Hoes, H. An aquifer thermal storage system in a Belgian hospital: Long-term experimental evaluation of energy and cost savings. Energy Build. 2011, 43, 3657-3665. [CrossRef]

41. Coccagna, M.; Cesari, S.; Valdiserri, P.; Romio, P.; Mazzacane, S. Impact of morphological and functional features on hospitals' energy consumption: A comparative analysis of six case studies. WSEAS Trans. Environ. Dev. 2018, 14, 212-225.

42. Fifield, L.J.; Lomas, K.J.; Giridharan, R.; Allinson, D. Hospital wards and modular construction: Summertime overheating and energy efficiency. Build. Environ. 2018, 141, 28-44. [CrossRef]

43. Ovchinnikov, P.; Borodinecs, A.; Strelets, K. Utilization potential of low temperature hydronic space heating systems: A comparative review. Build. Environ. 2017, 112, 88-98. [CrossRef]

44. Myhren, J.A.; Holmberg, S. Flow patterns and thermal comfort in a room with panel, floor and wall heating. Energy Build. 2008, 40, 524-536. [CrossRef]

45. Truüschel, A. Hydronic heating systems the effect of design on system sensitivity. Dr. Chalmers Tek. Högskola 2002, 1857, 1-226.

46. Jangsten, M.; Kensby, J.; Dalenbäck, J.-O.; Trüschel, A. Survey of radiator temperatures in buildings supplied by district heating. Energy 2017, 137, 292-301. [CrossRef]

47. Embaye, M.; AL-Dadah, R.K.; Mahmoud, S. Effect of flow pulsation on energy consumption of a radiator in a centrally heated building. Int. J. Low-Carbon Technol. 2016, 11, 119-129. [CrossRef]

48. Maivel, M.; Kurnitski, J. Low temperature radiator heating distribution and emission efficiency in residential buildings. Energy Build. 2014, 69, 224-236. [CrossRef]

49. Hasan, A.; Kurnitski, J.; Jokiranta, K. A combined low temperature water heating system consisting of radiators and floor heating. Energy Build. 2009, 41, 470-479. [CrossRef]

50. Myhren, J.A.; Holmberg, H. Performance evaluation of ventilation radiators. Appl. Therm. Eng. 2013, 51, 315-324. [CrossRef]

51. Hesaraki, A.; Bourdakis, E.; Ploskić, A.; Holmberg, S. Experimental study of energy performance in low-temperature hydronic heating systems. Energy Build. 2015, 109, 108-114. [CrossRef]

52. Ma, H.; Li, C.; Lu, W.; Zhang, Z.; Yu, S.; Du, N. Investigation on a solar-groundwater heat pump unit associated with radiant floor heating. Renew. Sustain. Energy Rev. 2017, 75, 972-977. [CrossRef]

53. Ala-Juusela, M. Heating and Cooling with Focus on Increased Energy Efficiency and Improved Comfort-Guidebook to IEA ECBCS Annex 37, Low Exergy Systems for Heating and Cooling of Buildings; VTT Technical Research Centre of Finland: Espoo, Finland, 2003.

54. Atienza Márquez, A.; Cejudo López, J.M.; Fernández Hernández, F.; Domínguez Muñoz, F.; Carrillo Andrés, A. A comparison of heating terminal units: Fan-coil versus radiant floor, and the combination of both. Energy Build. 2017, 138, 621-629. [CrossRef]

55. Legg, R. Unitary Systems. In Air Conditioning System Design, 1st ed.; Legg, R., Ed.; Butterworth-Heinemann: Oxford, UK, 2017; pp. 137-150.

56. Karmann, C.; Schiavon, S.; Bauman, F. Thermal comfort in buildings using radiant vs. all-air systems: A critical literature review. Build. Environ. 2017, 111, 123-131. [CrossRef]

57. Rhee, K.-N.; Olesen, B.W.; Kim, K.W. Ten questions about radiant heating and cooling systems. Build. Environ. 2017, 112, 367-381. [CrossRef]

58. Lin, B.; Wang, Z.; Sun, H.; Zhu, Y.; Ouyang, Q. Evaluation and comparison of thermal comfort of convective and radiant heating terminals in office buildings. Build. Environ. 2016, 106, 91-102. [CrossRef]

59. ASHRAE. 2016 ASHRAE Handbook-HVAC Systems and Equipment, Ch.6 Radiant Heating and Cooling; American Society of Heating, Refrigerating and Air-Conditioning Engineers: Atlanta, GA, USA, 2016. 
60. Bojić, M.; Cvetković, D.; Marjanović, V.; Blagojević, M.; Djordjević, Z. Performances of low temperature radiant heating systems. Energy Build. 2013, 61, 233-238. [CrossRef]

61. Martinopoulos, G.; Papakostas, K.T.; Papadopoulos, A.M. A comparative review of heating systems in EU countries, based on efficiency and fuel cost. Renew. Sustain. Energy Rev. 2018, 90, 687-699. [CrossRef]

62. Kazanci, O.B.; Shukuya, M.; Olesen, B.W. Exergy performance of different space heating systems: A theoretical study. Build. Environ. 2016, 99, 119-129. [CrossRef]

63. Bojić, M.; Cvetković, D.; Miletić, M.; Malešević, J.; Boyer, H. Energy, cost, and CO2 emission comparison between radiant wall panel systems and radiator systems. Energy Build. 2012, 54, 496-502. [CrossRef]

64. Dovjak, M.; Shukuya, M.; Krainer, A. Exergy Analysis of Conventional and Low Exergy Systems for Heating and Cooling of Near Zero Energy Buildings. Stroj. Vestn. J. Mech. Eng. 2012, 58, 453-461. [CrossRef]

65. Catalina, T.; Virgone, J.; Kuznik, F. Evaluation of thermal comfort using combined CFD and experimentation study in a test room equipped with a cooling ceiling. Build. Environ. 2009, 44, 1740-1750. [CrossRef]

66. Li, R.; Yoshidomi, T.; Ooka, R.; Olesen, B.W. Field evaluation of performance of radiant heating/cooling ceiling panel system. Energy Build. 2015, 86, 58-65. [CrossRef]

67. Su, L.; Li, N.; Zhang, X. Experimental study on cooling characteristics of concrete ceiling radiant cooling panel. Procedia Eng. 2015, 121, 2168-2175. [CrossRef]

68. Sui, X.; Zhang, X.; Han, X. Performance analysis on a residential radiant chilled ceiling system and evaluation on indoor thermal environment in summer: An application. Build. Serv. Eng. Res. Technol. 2012, 34, 317-331. [CrossRef]

69. Imanaria, T.; Omoria, T.; Bogakib, K. Thermal comfort and energy consumption of the radiant ceiling panel system: Comparison with the conventional all-air system. Energy Build. 1999, 30, 167-175. [CrossRef]

70. Khan, Y.; Khare, V.R.; Mathur, J.; Bhandari, M. Performance evaluation of radiant cooling system integrated with air system under different operational strategies. Energy Build. 2015, 97, 118-128. [CrossRef]

71. Syed, A. Advanced Building Technologies for Sustainability; John Wiley \& Sons: Hoboken, NJ, USA, 2012.

72. Miriel, J.; Serres, L.; Trombe, A. Radiant ceiling panel heating-cooling systems: Experimental and simulated study of the performances, thermal comfort and energy consumptions. Appl. Therm. Eng. 2002, 22, 1861-1873. [CrossRef]

73. CIBSE. Module 5: Radiant Heating Panel. CIBSE Journal. 2009. Available online: https://www.cibsejournal. com/cpd/modules/2009-06 (accessed on 10 October 2020).

74. Moslehi, S.; Maerefat, M.; Arababadi, R. Applicability of radiant heating-cooling ceiling panels in residential buildings in different climates of Iran. Procedia Eng. 2016, 145, 18-25. [CrossRef]

75. Stefiu, C. Energy and peak power savings potential of radiant cooling systems in US commercial buildings. Energy Build. 1999, 30, 127-138.

76. Maxim Integrated. DS1923. Available online: https://datasheets.maximintegrated.com/en/ds/DS1923.pdf (accessed on 10 October 2020).

77. Maxim Integrated. DS1921H. Available online: https://datasheets.maximintegrated.com/en/ds/DS1921HDS1921Z.pdf (accessed on 10 October 2020).

78. Shortridge Instruments. AirData Multimeter ADM-850L. Available online: http://shortridge.com/adm8501. html (accessed on 10 October 2020).

79. FLEXIM. FLUXUS ADM 6725. Available online: http://www.aysix.com/files/Flexim\%206725en.pdf (accessed on 10 October 2020).

80. FLIR. ThermaCAM PM675. Available online: https://www.termogram.com/pdf/675.pdf (accessed on 10 October 2020).

81. Fanger, P.O. Thermal Comfort: Analysis and Applications in Environmental Engineering; Danish Technical Press: Copenhagen, Denmark, 1970.

82. EN-ISO 7730. Ergonomics of the thermal Environment-Analytical Determination and Interpretation of Thermal Comfort Using Calculation of the PMV and PPD Indices and Local Thermal Comfort Criteria; International Standardization Organisation: Geneva, Switzerland, 2005.

83. ANSI/ASHRAE. Standard 55-2013: Thermal Environmental Conditions for Human Occupancy; American Society of Heating, Refrigerating and Air-Conditioning Engineers: Atlanta, GA, USA, 2013.

84. Athienitis, A.; O'Brien, W. Modeling, Design, and Optimization of Net-Zero Energy Buildings; Ernst \& Sohn: Berlin, Germany, 2015. 
85. Klein, S.A.; Beckman, W.A.; Mitchell, J.W.; Duffie, J.A.; Duffie, N.A.; Freeman, T.L.; Mitchell, J.C.; Braun, J.E.; Evans, B.L.; Kummer, J.P.; et al. TRNSYS Version 18; Solar Energy Laboratory, University of WisconsinMadison: Madison, WI, USA, 2018.

86. ISO 8996. Ergonomics of the Thermal Environment-Determination of Metabolic Rate; International Standardization Organisation: Geneva, Switzerland, 2004.

87. ISO 9920. Ergonomics of the Thermal Environment-Estimation of the Thermal Insulation and Evaporative Resistance of a Clothing Ensemble; International Standardization Organisation: Geneva, Switzerland, 2009.

Publisher's Note: MDPI stays neutral with regard to jurisdictional claims in published maps and institutional affiliations.

(C) 2020 by the authors. Licensee MDPI, Basel, Switzerland. This article is an open access article distributed under the terms and conditions of the Creative Commons Attribution (CC BY) license (http://creativecommons.org/licenses/by/4.0/). 